\title{
Good acting secret of successful BI
}

The theme of the March 27, 1992, meeting of upstate New York's Forum for Library Instruction was "Library Instruction in a Television Age: How to Deal with the Competition."

William E. Connors, dean of the Library and Information Technology at SUNY-New Paltz, and a skilled actor who has appeared in films, commercials, and plays, contended that teaching (including bibliographic instruction) is theater. Students don't feel that BI is essential, and we, as BI librarians, have to be actors to keep them awake. Our success in BI depends on our ability to act, to strike people with what we are saying, and to give them a hook on which to hang the information. It is crucial to know your subject, your story, your audience, and perhaps most importantly, you need to know when to stop!

Borrowing from Uta Hagen's book Respect for Acting (1973), BI librarians should ask themselves: What am I doing here? Why were these people brought together and who am I in relationship to them? What do I have to contend with (this may be as simple as the class timeafter lunch can be deadly)? What do I want from the students? What is hampering me from getting information across? How can I break through the wall of resistance put up by the students? Connors suggested that one way to do this is to catch students at the point of their not knowing, yet knowing they need to know. In other words, providing an introduction to the library to students without an assignment may not be effective, while teaching students about to confront a term paper might be successful. A specific acting technique Connors suggested using is talking to specific people as you teach. By focusing on different people as the class progresses, everyone has a chance to be involved. He likened the teacher who does not talk to anyone in particular to the voice on the loudspeaker in subway cars that does not talk directly to anyone-even though everyone hears it, nobody is really listening.

Connors encouraged those who do BI to look at teaching as acting, as taking on the role of someone who knows something important for those who are sitting in front of us. If we do so, our students will stay with us. The group then previewed the new $\mathrm{H}$. W. Wilson video,
Discovering the College Library, and discussed its strong points (its sense of humor, the use of a student as a peer tutor, the approachability of the librarian) and its weak points (no logical order to the presentation, no minority representation, its lack of definitions, and its length).

Tom Demenkoff, assistant for instructional resources at SUNY-New Paltz and a former Broadway and television actor and producer of educational audio- and videotapes, shared his expertise in critiquing this video and in planning one's own. He emphasized that librarians can use video as a bridge to students as long as it speaks their own language. Students have

\section{He likened the teacher who does} not talk to anyone in particular to the voice on the loudspeaker

$$
\begin{aligned}
& \text { in subway cars -even though } \\
& \text { everyone bears it, no one is } \\
& \text { really listening. }
\end{aligned}
$$

grown up with video and accept information from it. But the videos need to be short and contain strong visuals, such as animation or computer graphics. Other key components include music that appeals to students, a plot they can relate to, and a "you are there" sense of reality achieved with a roving camera. Demenkoff does not see a video replacing a librarian, but to be used as a "jump start" to bring people together. He felt the Wilson video was too clean and staged, and reported that students he showed it to were bored.

In order to demonstrate his ideas about what would make an effective library instruction video, Demenkoff will be working with Sarah Vasse, Orange County Community College; Lucille Brown, SUNY-New Paltz; and Kappa Waugh, Vassar College, to develop a three-tofive-minute pilot video on finding business information in periodicals. The Forum hopes to use this pilot to attract funding for a series of short videos on doing research. The pilot will be shown at the fall meeting of the Forum for Library Instruction.--Trudi E. Jacobson, SUNYAlbany, Bitnet: TJ662@ALBNYVMS 